PEMBELAJAR: Jurnal Ilmu Pendidikan, Keguruan, dan Pembelajaran

Volume 1 Nomor 1 April 2017

e-ISSN: 2549-9114 dan p-ISSN: 2549-9203

(Received: Februari-2017; Reviewed: Maret-2017; Published: April 2017)

\title{
Penggunaan Teknik Ice Breaking Untuk Meningkatkan Jiwa Kewirausahaan Siswa Di Sekolah Menengah Kejuruan (SMK)
}

\author{
Algha Sanjaya \\ Psikologi Pendidikan dan Bimbingan, Fakultas Ilmu Pendidikan \\ Universitas Negeri Makassar \\ Corresponding e-mail: algha.sanjaya15@gmail.com
}

\begin{abstract}
Abstrak: Penelitian ini menelaah Teknik Ice Breaking Melalui Bimbingan Karier untuk Meningkatkan Jiwa Kewirausahaan Siswa di Sekolah Menengah Kejuruan (SMK). Masalah utama penelitian ini adalah: 1. Bagaimana gambaran tingkat jiwa kewirausahaan siswa di SMK? 2. Bagaimana penggunaan teknik ice breaking sebagai solusi efektif untuk meningkatkan jiwa kewirausahaan siswa di SMK? Tujuan penelitian ini adalah: 1. Untuk mengetahui gambaran tingkat jiwa kewirausahaan siswa di SMK. 2. Untuk mengetahui teknik ice breaking sebagai solusi efektif untuk meningkatkan jiwa kewirausahaan siswa di SMK. Penelitian ini menggunakan metode studi pustaka (Library Research) dengan mengumpulkan data-data dari berbagai sumber yang relevan, kemudian peneliti memaparkan pemecahan masalah melalui sintesis dan menarik kesimpulan. Hasil penelitian menunjukkan bahwa: 1. Tingkat jiwa kewirausahaan siswa di SMK masih rendah. 2. Penggunaan teknik ice breaking melalui bimbingan karier sebagai solusi efektif yang ditawarkan peneliti untuk meningkatkan jiwa kewirausahaan siswa di SMK.
\end{abstract}

Kata Kunci: Teknik Ice Breaking, Jiwa Kewirausahaan, Siswa, SMK

\begin{abstract}
This study examines Ice Breaking Techniques Through Career Guidance to Improve Student Entrepreneurship Soul in Vocational Secondary School (SMK). The main problems of this research are: 1. How is the description of student entrepreneurship spirit in SMK? 2. How to use ice breaking technique as an effective solution to improve student entrepreneurship spirit in SMK? The purpose of this study are: 1 . To know the description of the level of student entrepreneurship spirit in SMK. 2. To know ice breaking technique as an effective solution to improve student entrepreneurship spirit in SMK. This research uses library research method by collecting data from various relevant sources, then researcher explain problem solving through synthesis and draw conclusion. The results showed that: 1. The level of entrepreneurship of students in SMK is still low. 2. The use of ice breaking technique through career guidance as an effective solution offered by researchers to improve students entrepreneurship spirit in SMK.
\end{abstract}

Keywords: Ice Breaking Technique, Entrepreneurship Soul, Student, SMK 


\section{PENDAHULUAN}

Arus globalisasi semakin bertambah cepat, hal ini ditandai dengan perkembangan ilmu pengetahuan, teknologi, dan seni yang semakin pesat. Globalisasi akan berdampak pada semua aspek kehidupan, salah satunya aspek pendidikan. Fenomena tersebut menciptakan suasana persaingan yang sangat ketat antara manusia satu dengan yang lain. Manusia dituntut untuk berpikir dan berperilaku yang terbaik untuk dapat bertahan dan sukses pada kehidupan modern saat ini. Sebagai contoh dalam menghadapi dunia pekerjaan seseorang harus mempunyai keterampilan khusus serta diakui oleh lembaga resmi, tidak hanya bermodalkan ijazah sekolah yang dimiliki. Untuk itu, semua negara-negara di dunia telah menyiapkan sumber daya manusia yang kreatif dan produktif agar mempunyai daya saing atau kompetitif.

Begitu juga dengan Indonesia sebagai negara berkembang, terus melakukan upaya untuk meningkatkan sumber daya manusia yang masih berkualitas rendah dibanding negara lainnya. Hal tersebut sesuai dengan data dari Institute of Management Development (IMD) yang merupakan lembaga pendidikan bisnis terkemuka di Swiss, telah melaporkan hasil penelitian yang berjudul IMD World Talent Report 2015. Dalam laporan tersebut dinyatakan bahwa peringkat Indonesia turun ke 16 dari peringkat 25 pada tahun 2014 dan menjadi peringkat 41 pada tahun 2015. Posisi Indonesia berada jauh di bawah posisi negara tetangga seperti Singapura, Malaysia, bahkan Thailand. Posisi
Indonesia juga hanya sedikit lebih baik dari Filipina. Peringkat ini dihitung dengan bobot tertentu dengan mempertimbangkan tiga faktor yaitu faktor pengembangan dan investasi, faktor daya tarik suatu negara, dan faktor kesiapan sumber daya manusia. Masing-masing faktor terbagi lagi ke dalam beberapa rincian lainnya (IMD, 2015). Akibat dari kualitas sumber daya manusia yang rendah, salah satu dampak negatif yang ditimbulkan adalah meningkatnya kemiskinan di Indonesia.

Badan Pusat Statistik Indonesia (2015) mencatat kemiskinan di Indonesia terus meningkat yakni bulan Agustus tahun 2014 hingga Agustus 2015 sebanyak 5,94\% menjadi $6,18 \%$. Selain sumber daya manusia yang rendah, jumlah pencari kerja dan lapangan kerja yang tidak seimbang menyebabkan ketimpangan dalam dunia kerja. Sebagian besar masyarakat Indonesia, mulai dari pekerja tidak terdidik, terlatih, maupun terdidik lebih memilih sebagai pencari kerja (job seeker) daripada pencipta kerja (job creator) (Handayani, 2015). Fenomena tersebut menyebabkan tingkat kemiskinan dan pengangguran yang tinggi tiap tahun di Indonesia.

Menurut Badan Pusat Statistik Indonesia, pada bulan Februari 2016 tingkat pengangguran terbuka tertinggi adalah pada jenjang pendidikan Sekolah Menengah Kejuruan (SMK) sebesar 9,84\%. Angka tersebut meningkat $0,79 \%$ dibandingkan Februari 2015" (Jefriando, 2016). Berikut adalah data mengenai rincian tingkat pengangguran terbuka di Indonesia sampai per Februari 2016. 
Tabel 1. Data Tingkat Pengangguran di Indonesia

\begin{tabular}{cll}
\hline No & \multicolumn{1}{c}{ Jenjang } & Angka \\
\hline 1. & Sekolah Dasar ke bawah & $3,44 \%$ \\
\hline 2. & Sekolah Menegah Pertama/Sederajat & $5,76 \%$ \\
\hline 3. & Sekolah Menegah Atas/Sederajat & $6,95 \%$ \\
\hline 4. & Sekolah Menengah Kejuruan/Sederajat & $9,84 \%$ \\
\hline 5. & Diploma I, II, dan III & $7,22 \%$ \\
\hline 6. & Universitas & $6,22 \%$ \\
\hline
\end{tabular}

Sumber: Jefriando, 2016.

Dari data di atas, sekolah mengah kejuruan menempati peringkat pertama sebagai jumlah pengangguran terbuka tertinggi di Indonesia. Hal tersebut kontradiksi dengan tujuan umum pengadaan sekolah menengah kejuruan. Sesuai dengan Undang-Undang Republik Indonesia Nomor 20 Tahun 2003 tentang Sistem Pendidikan Nasional menyebutkan, seharusnya pendidikan kejuruan merupakan pendidikan menengah yang mampu mempersiapkan siswa untuk bekerja dalam bidang tertentu. Lainnya, ditegaskan kembali di dalam peraturan Pemerintah Republik Indonesia Nomor 17 tahun 2010 bahwa Pendidikan Menengah Kejuruan adalah pendidikan yang membekali siswa dengan kemampuan ilmu pengetahuan dan teknologi serta kecakapan kejuruan para profesi sesuai dengan kebutuhan masyarakat.

Berdasarkan uraian tersebut, maka dapat disimpulkan sekolah kejuruan adalah lembaga pendidikan yang menyiapkan siswa dengan kompetensi dibidang kejuruan tertentu melalui teori maupun praktik dengan harapan setelah lulus dapat langsung bekerja untuk memenuhi dunia kerja. Kemudian, lulusan sekolah menengah kejuruan diharapkan tidak hanya sebagai pencari kerja namun juga pencipta kerja. Dalam kurikulum sekolah menengah kejuruan telah dijelaskan, siswa diajari untuk mandiri dan menciptakan pekerjaan sesuai dengan kejuruan yang digeluti. Namun nyatanya, sebagian besar lulusan sekolah kejuruan hanya menjadi pencari kerja atau karyawan dibanding menciptakan pekerjaan untuk dirinya sendiri dan orang lain yakni berwirausaha.

Wirausaha dipandang sebagai pekerjaan yang baik dan strategis untuk menghadapi dunia global, baik untuk keuntungan pribadi maupun negara. Pekerjaan wirausaha akan mendatangkan pelbagai manfaat dan keuntungan dari pada jenis pekerjaan lainnya, seperti yang diungkapkan Pratiwi (2009) yaitu:

"Manfaat dari wirausaha yaitu sebagai sumber penciptaan dan perluasan kesempatan kerja, pelaksana pembangunan bangsa dan negara, menjadi contoh bagi anggota masyarakat lain, hidup secara efisien dan sederhana, memelihara keserasian lingkungan baik dalam pergaulan maupun kebersihan lingkungan. Sedangkan keuntungan wirausaha yakni terbuka peluang untuk mencapai tujuan yang dikehendaki sendiri, terbuka peluang untuk mendemontrasikan potensi secara penuh, terbuka peluang untuk memperoleh manfaat dan keuntungan secara maksimal, terbuka peluang untuk membantu masyarakat dengan usaha-usaha konkrit, 
terbuka kesempatan untuk menjadi bos".

Hal tersebut juga diungkapkan oleh Presiden Republik Indonesia Joko Widodo (dalam http://bisnis.tempo.co., 2016) saat membuka Jambore Himpunan Pengusaha Muda Indonesia (HIPMI) Perguruan Tinggi Se-ASEAN 2016 di Kampus Telkom University Bandung, Senin 23 Mei 2016 "Indonesia membutuhkan 5,8 juta pengusaha muda baru, apabila ingin memenangkan kompetisi di era pasar tunggal Masyarakat Ekonomi Asean (MEA). Pasalnya, jumlah pengusaha yang ada saat ini jumlahnya hanya mencapai 1,56 persen padahal standarisasi bank dunia menyaratkan 4 persen". Maka dari itu, pekerjaan wirausaha sangat penting terutama untuk lulusan sekolah menengah kejuruan.

Namun nyatanya minat berwirausaha di Indonesia masih sangat rendah. Jumlah wirausahawan di Indonesia hanya $0,18 \%$ dari jumlah penduduk, masih jauh di bawah negara lain yaitu Malaysia $2 \%$, Amerika 4\%, dan Singapura sudah mencapai 7\% (Aprilianty, 2012). Maka dari itu, tidak heran jika menurut Tyagita (2013) Indonesia berada pada $1,65 \%$ atau berada di urutan ke 68 dari 121 negara dalam The Global Entrepreneurship \& Development Index 2013. Begitupun juga dengan lulusan SMK, menurut data Badan Pusat Statistik Indonesia (2014) sekitar 1,3 juta lulusan SMK masih banyak yang belum mendapatkan pekerjaan, menurut Khairul (dalam Tyagita, 2013) sebanyak 85\% lulusan SMK langsung bekerja, $8 \%$ melanjutkan kuliah dan $1-1,5 \%$ lulusan SMK yang berwirausaha.

Untuk meningkatkan jiwa kewirausahaan siswa di sekolah agar menjadi wirausahawan yang baik, bukan hanya tanggungjawab guru mata pelajaran kewirausahaan namun juga guru bimbingan dan konseling. Dalam Peraturan Menteri Pendidikan dan Kebudayaan Republik Indonesia (Permendikbud) Nomor 111 tahun 2013 Tentang Bimbingan dan Konseling pada Pendidikan Dasar dan Pendidikan Menengah, disebutkan bahwa layanan bimbingan dan konseling memiliki tujuan membantu konseli mencapai perkembangan optimal dan kemandirian secara utuh dalam aspek pribadi, belajar, sosial, dan karier. Artinya guru bimbingan dan konseling atau konselor mempunyai tugas dan kewajiban untuk membantu meningkatkan kualitas hidup siswa termasuk dalam karier sebagai wirausaha.

Guru bimbingan dan konseling dapat menggunakan layanan bimbingan karier untuk meningkatkan jiwa kewirausahaan siswa. Di dalam Peraturan Menteri Pendidikan dan Kebudayaan (Permendikbud) Nomor 111 tahun 2014 menjelaskan bimbingan dan konseling karier adalah suatu proses pemberian bantuan konselor atau guru bimbingan dan konseling kepada siswa/konseli untuk mengalami pertumbuhan, perkembangan, eksplorasi, aspirasi dan pengambilan keputusan karier sepanjang rentang hidupnya secara rasional dan realistis berdasar informasi potensi diri dan kesempatan yang tersedia di lingkungan hidupnya sehingga mencapai kesuksesan dalam kehidupannya.

Dalam penelitian ini, peneliti menelaah penggunaan teknik ice breaking dalam layanan bimbingan karier. Menurut Mahfud (2010) dan Nilda (2011) teknik Ice Breaking yakni aktivitas kecil dalam suatu kegiatan untuk pengenalan, memecahkan atau mencairkan suasana yang kaku seperti es, meningkatkan semangat dan motivasi, serta bahan evalusasi. Teknik Ice Breaking berpotensi mampu manarik perhatian siswa pada saat pemberian bimbingan karier tentang kewirausahaan oleh guru bimbingan dan konseling. Ice breaking ini 
diberikan kepada siswa dalam bentuk bermain,dimana dapat diberikan dalam bentuk kegiatan kelompok oleh guru (Bakhtiar, 2015). Setelah guru bimbingan dan konseling melakukan intervensi, siswa mampu memahami materi tentang kewirausahaan dengan lebih baik, sehingga meningkatkan jiwa kewirausahaan yang lebih tinggi dan mampu merencanakan masa depan dengan baik sebagai wirausaha.

\section{METODE}

Tulisan ini bersifat studi pustaka yaitu mengenai solusi dalam meningkatkan jiwa kewirausahaan siswa di Sekolah Menengah Kejuruan (SMK) dengan menggunakan teknik ice breaking dalam layanan bimbingan karier. Teknik pengumpulan data yang dilakukan adalah melalui studi pustaka dengan mengumpulkan data-data dari berbagai sumber yang terkait dengan permasalahan yang dibahas. Dalam studi pustaka, sumber-sumber yang digunakan adalah berasal dari berbagai literatur seperti buku buku, jurnal ilmiah, disertasi, e.book, internet dan berbagai data serta fakta yang ada dalam masyarakat dan sumber lainnya yang relevan serta dapat dipertanggungjawabkan. Studi pustaka ini dilakukan untuk menggali informasi mengenai permasalahan yang dibahas. Setelah penulis menemukan literatur-literatur yang relevan, kemudian menganalis data sesuai dengan masalah yang diangkat. Setelah data tersebut dianalisis, peneliti memaparkan pemecahan masalah melalui sintesis dan menarik kesimpulan serta memberi rekomendasi dalam pengimplementasian gagasan dalam penelitian ini.

Menurut Mahfud (2010), teknik ice breaking adalah suatu aktivitas kecil dalam suatu kegiatan yang bertujuan agar siswa merasa nyaman dengan lingkungan barunya. Kegiatan ini biasanya berupa suatu humor, kadang berupa kegiatan yang berbentuk kegiatan pemberian informasi, pencerahan atau dapat juga dalam bentuk permainan sederhana. Teknik ice breaking digunakan untuk memecah kebekuan pada saat awal, saat, atau akhir kegiatan. Teknik ice breaking digunakan untuk proses pengenalan antara siswa satu yang lainnya pada saat awal kegiatan. Kemudian apabila siswa mulai bosan dengan materi yang berat maka teknik ice breaking dapat dilakukan untuk meningkatkan motivasi yang berkaitan dengan kegiatan tersebut. Terakhir, teknik ice breaking dapat digunakan pada saat akhir kegiatan yang bertujuan untuk mengevaluasi kegiatan dengan materi yang telah diberikan kepada siswa.

Kajian hasil pemikiran mendalam terkait dengan optimalisasi penggunaan teknik ice breaking dalam layanan bimbingan karier belum banyak diterapkan dalam meningkatkan jiwa kewirausahaan pada siswa. Sehingga, pada penelitian kali ini akan mengkaji lebih dalam teknik tersebut dengan media permainan monopoli untuk meningkatkan jiwa kewirausahaan siswa di SMK.

\section{HASIL DAN PEMBAHASAN}

Wirausaha menurut Kamus Besar Bahasa Indonesia (KBBI) adalah orang yang pandai atau berbakat mengenali produk baru, menentukan cara produksi baru, menyusun operasi untuk pengadaan produk baru, memasarkannya, serta mengatur permodalan operasinya (Anwar, 2001). Sementara itu, menurut Kemendiknas (2013), Kewirausahaan merupakan suatu sikap, jiwa dan kemampuan untuk menciptakan sesuatu yang baru yang sangat bernilai dan berguna bagi dirinya dan orang lain. Sedangkan Hodgetts (2006), menyatakan " entrepreneurs are uniquely optimistic, hard-driving, committe individuals who derive great satisfaction from being independent. Starting a new business requires more than just an idea: it requires a special person, an entrepreneur, who uses sound judgment and planning along with risk taking to ensure the success of his or her own business".

Untuk menjadi seorang wirausaha harus mempunyai karakter atau jiwa kewirausahaan. Jiwa kewirausahaan berperan sebagai pendorong terciptanya kewirausahaan yang sukses. Jiwa kewirausahaan merupakan bagian dari ranah afektif yang perlu ditanamkan pada siswa sebagai bekal kelak ketika terjun dikehidupan masyarakat (Karli, 2012). Potensi jiwa kewirausahaan yang bisa dikembangkan di 
dunia pendidikan adalah kemampuan berpikir kreatif, inovatif, percaya diri, disiplin, jujur, tanggungjawab, mandiri, kerja keras, kerjasama, rasa ingin tahu, berorientasi pada hasil, berani mengambil risiko, kepemimpinan, pantang menyerah, komitmen, realistis, komunikatif, dan memiliki motivasi kuat untuk sukses (Kemendiknas, 2013).

Dalam hal meningkatkan jiwa kewirausahaan siswa di SMK, guru bimbingan dan konseling mempunyai peran sangat penting sesuai dengan amanat Peraturan Menteri Pendidikan dan Kebudayaan Republik Indonesia (Permendikbud) Nomor 111 tahun 2014 Tentang Bimbingan dan Konseling pada Pendidikan Dasar dan Pendidikan Menengah. Guru bimbingan dan konseling dapat menggunakan layanan bimbingan karier yakni suatu proses pemberian bantuan konselor atau guru bimbingan dan konseling kepada siswa untuk mengalami pertumbuhan, perkembangan, eksplorasi, aspirasi dan pengambilan keputusan karier sepanjang rentang hidupnya secara rasional dan realistis berdasar informasi potensi diri dan kesempatan yang tersedia di lingkungan hidupnya sehingga mencapai kesuksesan dalam kehidupannya (Permendikbud, 2014).

Pada saat pelaksanaan layanan bimbingan karier, guru bimbingan dan konseling harus mempunyai strategi yang baik dan efektif agar dapat mencapai tujuan yang dikehendaki. Dalam pembahasan ini, peneliti menawarkan strategi bimbingan karier melalui pendekatan kelompok dengan paket belajar. Pendekatan kelompok dipilih karena dipandang lebih efektif dalam penggunaan waktu dan tenaga guru bimbingan dan konseling di SMK. Selain itu, dalam layanan bimbingan karier kali ini menggunakan teknik ice breaking sehingga pendekatan kelompok sangat diutamakan.

Lainnya, paket belajar dipilih agar guru bimbingan dan konseling dapat memberikan pemahaman dasar mengenai keadaan diri dan lingkungan terlebih dahulu yang berkaitan dengan kewirausahaan. Pada proses ini mengacu pada pemberian pemahaman diri dan lingkungan, serta merencanakan masa depan kepada siswa melalui analisis Strenghths, Weakness,
Opportunities, dan Threats (SWOT). Namun peneliti memilih beberapa pokok bahasan yang peneliti anggap penting untuk mendukung penelitian ini. Dengan demikian, strategi tersebut memudahkan siswa dalam proses intervensi selanjutnya yakni menggunakan teknik ice breaking. Adapun materi yang peneliti pilih adalah:

1. Mengenal diri sendiri

2. Mengenal dunia kewirausahaan

3. Kisah tokoh sukses dalam dunia wirausaha yang akan dilakukan dengan pendekatan tersebut.

Pemberian materi tentang kewirausahaan kepada siswa tidak mudah, karena materi tersebut dianggap baru dan kurang menarik bagi siswa. Apalagi pekerjaan sebagai wirausaha kurang diminati oleh orangtua dan siswa sendiri. Sehingga hal ini harus menjadi pertimbangan bagi guru bimbingan dan konseling dalam pemberikan layanan bimbingan karier dengan tujuan meningkatkan jiwa kewirausahaan. Pemilihan teknik ice breaking sangat cocok pada keadaan di atas, teknik tersebut sering dijumpai dalam pelbagai kegiatan baik formal maupun informal. Menurut Mahfud (2010), teknik Ice Breaking adalah suatu aktivitas kecil dalam suatu acara yang bertujuan agar siswa merasa nyaman dengan lingkungan barunya. Kegiatan ini biasanya berupa suatu humor, kadang berupa kegiatan yang berbentuk kegiatan pemberian informasi, pencerahan atau dapat juga dalam bentuk permainan sederhana.

Tujuan dilaksanakan teknik Ice Breaking dikemukakan oleh Nilda (2011) adalah sebagai berikut:

1. Terciptanya kondisi-kondisi yang equal (setara) antara sesama siswa dalam suatu kegiatan.

2. Menghilangkan sekat-sekat pembatas di antara siswa lainnya.

3. Terciptanya kondisi dinamis antar siswa.

4. Menimbulkan kegairahan (motivasi) pada siswa untuk mengikuti kegiatan bimbingan dan konseling yang sedang berlangsung. Sehingga siswa dapat fokus kembali untuk menerima materi yang disampaikan.

Pada penggunaan teknik ice breaking kali ini menggunakan metode simulasi dan 
permainan yakni monopoli. Peneliti menawarkan metode tersebut dalam proses bimbingan karier melalui pendekatan kelompok dengan metode paket belajar, dengan alasan lebih praktis dan menyenangkan untuk siswa. Ananda (2013) dan Maryan (2011) mengungkapkan bahwa salah satu manfaat permainan monopoli sebagai media belajar memanejemen keuangan serta melatih kewirausahaan. Berikut adalah penjelasan Ananda (2013) mengenai nilai sikap yang terkandung dalam permainan monopoli sebagai berikut:

1. Manajemen masalah (Problem Solving)

2. Menghindari hutang

3. Mengatur uang dengan bijak

4. Mempunyai semangat dan tujuan hidup kedepan

5. Efektivitas keuangan dan negosiasi

6. Meningkatkan Interaksi sosial

7. Mengasah keterampilan

8. Mengenalkan pelajaran hidup

9. Kontrol diri
Dari pelbagai manfaat dari permainan monopoli, diketahui baha permainan tersebut mengandung banyak karakteristik jiwa kewirausahaan sesuai dengan penjelasan Kemendiknas (2013) yakni kemampuan berpikir kreatif, inovatif, percaya diri, disiplin, jujur, tanggungjawab, mandiri, kerja keras, kerjasama, rasa ingin tahu, berorientasi pada hasil, berani mengambil risiko, kepemimpinan, pantang menyerah, komitmen, realistis, komunikatif, dan memiliki motivasi kuat untuk sukses.

Melalui penggunaan teknik ice breaking yang mengandung indikator-indikator seorang wirausaha yang baik, diharapkan mampu meningkatkan jiwa kewirausahaan siswa di SMK. Sehingga penggunaan teknik ice breaking dalam bimbingan karier berpotensi mampu meningkatkan jiwa kewirausahaan siswa dengan lebih efektif, akhirnya siswa mampu memahami dengan baik tentang kewirausahaan dan merencanakan karier untuk masa depannya sebagai seorang wirausaha.

Tabel 2. konsep pelaksanaan layanan bimbingan karier melalui teknik ice breaking.

\begin{tabular}{|c|c|c|c|}
\hline Kegiatan & Tujuan & Skenario & Waktu \\
\hline $\begin{array}{l}\text { Layanan } \\
\text { Bimbingan } \\
\text { Karier }\end{array}$ & $\begin{array}{l}\text { Untuk memberikan informasi dan } \\
\text { pemahaman tentang karier, } \\
\text { terutama kewirausahaan }\end{array}$ & $\begin{array}{l}\text { 1. Perkenalan } \\
\text { 2. Membangun hubungan } \\
\text { 3. Menjelaskan tujuan, azas, } \\
\text { dan waktu dalam kegiatan } \\
\text { ini } \\
\text { 4. Pemberian materi tentang } \\
\text { jiwa kewirausahaan } \\
\text { dengan menggunakan } \\
\text { pendekatan kelompok } \\
\text { melalui paket belajar } \\
\text { 5. Penerapan teknik Ice } \\
\text { Breaking menggunakan } \\
\text { permainan Monopoli } \\
\text { 6. Berdiskusi untuk } \\
\text { mengevaluasi siswa } \\
\text { 7. Rangkuman } \\
\text { 8. Penutup }\end{array}$ & $\begin{array}{c}90 \\
\text { menit }\end{array}$ \\
\hline
\end{tabular}

\section{KESIMPULAN}

Hasil penelitian ini menjelaskan bahwa tingkat jiwa kewirausahaan siswa di Sekolah 
Menengah Kejuruan (SMK) masih rendah. Sehingga diperlukan strategi bimbingan karier yang baik dan efektif sebagai upaya peran guru yakni melalui penggunaan teknik ice breaking dalam layanan bimbingan karier. Kemudian atas dasar keterbatasan peneliti, maka penulis memberikan saran: (1) Penelitian selanjutnya menggunakan metode lainnya agar lebih valid, (2) Media yang telah ada dimodifikasi sedemikian rupa sehingga lebih baik.

\section{DAFTAR PUSTAKA}

Ananda, Kun Sila. 2013. 5 Pelajaran Keuangan Dari Permainan Monopoli. [On line] https://www.merdeka.com/gaya/5pelajaran-keuangan-dari-permainanmonopoly.html. diakses 2 Desember 2016. Anonim.

https://bisnis.tempo.co/read/news/2016/05/ 23/092773404/menangkan-mea-jokowi-riperlu-5-8-juta-pengusaha-muda-baru. Diakses 2 Desember 2016.

Anonim.

https://www.bps.go.id/Brs/view/id/1196.

Diakses 2 Desember 2016.

Anwar, Dessy. 2001. Kamus Lengkap Bahasa Indonesia. Surabaya: Karya Abditama.

Aprilianty, Eka. 2012. Pengaruh Kepribadian Wirausaha, Pengetahuan Kewirausahaan, dan Lingkungan Terhadap Minat Berwirausaha Siswa SMK. Kalimantan Tengah: Pangkalan Bun.

Bakhtiar, Ilham M. (2015). Pengembangan Video Ice Breaking Sebagai Media Bimbingan Konseling Dalam Meningkatkan Keterampilan Sosial. Jurnal Psikologi Pendidikan \& Konseling, 1(2), 150-163.

Handayani, Putri. 2015. Job Seeker VS Job Creator. Jakarta: Universitas Gunadarma.

IMD. 2015. IMD World Talent Report 2015. [On line] http://www.imd.org. Diakses 2 Desember 2016.

Jefrindo, Maikel. 2016. Pengangguran Terbesar RI Adalah Lulusan SMK. [On line] http://finance.detik.com/ekonomibisnis/3203625/pengangguran-terbesar-riadalah-lulusan-smk. diakses 2 Desember 2016.
Karli, Hilda. 2012. Pembelajaran Tematik untuk Meningkatkan Jiwa Kewirausahaan. Jurnal Pendidikan Penabur- No 19//tahun ke 11 .

Kementerian Pendidikan dan Kebudayaan Republik Indonesia. 2014. Peraturan Menteri Pendidikan dan Kebudayaan Republik Indonesia Nomor 111 tahun 2014 Tentang Bimbingan dan Konseling Pada Pendidikan Dasar dan Pendidikan Menengah. Jakarta: Kemendikbud RI.

Mahfud, S. 2010. Teknik Ice Breaking dalam Kelompok. Jakarta: Rineke Cipta.

Maryan, Edwin Anangga Maryan. Perancangan Permainan Sebagai Alat Bantu Pembelajaran Karakter Wirausaha Pada Mata Pelajaran Kuliah Kewirausahaan (Studi Kasus Mata Kuliah Kewirausahaan jurusan Teknik Industri UNS). Surakarta: UNS.

Nilda. 2011. Varian Ice Breaker: Segarkan Aktivitas Pembelajaran. [On line] http://www.komunikasi.um.ac.id. Diakses 2 Desember 2016.

Pratiwi, Ari Suci. 2009. Upaya meningkatkan Minat Berwirausaha Melalui Layanan informasi Karier Pada Siswa Kelas XI SMA Negeri 1 Kradenan Kabupaten Grobogan Tahun Ajaran 2008/2009.

Tyagita, Brigitta Putri Atika. 2013. Edupreneur Dalam Meningkatkan Mutu Lulusan SMK. Salatiga: Universitas Kristen Satya Wacana. 